metamorphic domain is marked by an antiform in gnaissic diatexites. A normal fault with average northeastward dip limits the fold and juxtaposes upper kianite-staurolite bearing micaxists. From this limit, the structural pattern of Aiuruoca-Andrelândia Nappe is homogeneous, with sinmetamorphic ductile shear-sense indicators to E-NE.

The alternating of extensional structures in a general compressive regime and in the hind portion of high-pressure nappe, is associated with the extrusion process and with the search, in the collisional orogen, of isostatic balance. - ( December 14, 2001 ).

\footnotetext{
* Supported by FAPESP 00/11390-4 and 98/15624-8.
}

\section{FACIES AND SEQUENCE STRATIGRAPHY OF THE ITARARÉ AND GUATÁ SUBGROUPS (LATE PALEO- ZOIC), NORTHERN PARANÁ BASIN, BRAZIL*}

Antonio M. Chaves-Junior and José R. Canuto**

Instituto de Geociências, USP, São Paulo, SP.

Presented by Antonio C. Rocha-CAmpos

Glacial advances and retreats influenced relative sea level change, concomitantly to the regional subsidence during the deposition of a $2^{\text {nd }}$ order Permo-Carboniferous sequence in northern Santa Catarina State, Paraná Basin.

According to Canuto's (1999) nomenclature, the following facies were recognized in the Itararé and in the lower part of the Guatá Subgroups: a) compacted massive diamictite; b) uncompacted massive diamictite; c) lenticular diamictite; d) low-angle, cross-bedded and truncated wave-ripple-laminated sandstone; e) truncated low-angle, cross-bedded, tabular sandstone; f) low-angle, bidirecional, cross-bedded, tabular sandstone; g) crossbedded, fining-upward sandstones; h) massive or laminated shale; i) massive siltstone; j) interlaminated very fine sandstone and silty shale. Some of them corresponding to diagnostic facies of facies associations (\#).

Facies associations recognized are: $A_{1}$, compacted massive (\#), uncompacted massive (\#) and lenticular diamictites; $A_{2}$, truncated low-angle cross-bedded tabular sandstone (\#); $\mathrm{A}_{3}$, massive or laminated shale (\#) and massive siltite (\#); $\mathrm{A}_{4}$, interlaminated (\#), low-angle cross-bedded and truncated wave ripple laminated sandstone and low-angle bidirecional cross-bedded tabular sandstone (\#); and corresponding, respectively, lowstand, transgressive, highstand and glacio-isostatic regressive system tracts.

In view of the recognized associations of facies, it is verified that the sedimentary succession comprises two partial $3^{\text {rd }}$ order sequences, representing the upper part of one (associations $\mathrm{A}_{3}$ and $\mathrm{A}_{4}$ ) and the basal and intermediate parts of the overlying one (associations $\mathrm{A}_{1}, \mathrm{~A}_{2}$ and $\left.\mathrm{A}_{3}\right)$.

The analysis of the sedimentary succession shows, from the base to the top, that the shales were deposited in a mudflat environment, followed by the deposition of sandstones in a lower shoreface setting, sandstones in upper shoreface, the interlaminated in tidal flat/foreshore, glacial advance, glacio-isostatic subsidence possibly until a compatible shoreface depth, disintegration and retreat of the glacier, slow rise of the sea level until the establishment of the foreshore/tidal flat, shoreface environment again due to a greater rise of the relative sea level than the last one, beginning of glacio-isostatic uplift by the final retreat of the glacier, return of the foreshore conditions, possibly still the backshore setting, and, finally, deltaic progradation over foreshore and/or backshore settings. - ( December 14, 2001 ).

* Supported by FAPESP 97/13973-2.

**E-mail: jrcanuto@usp.br.

\section{THE PIUMHI SUPERGROUP, SW-SÃO FRANCISCO CRATON, MG-BRAZIL}

Alexandre P. Chiarini ${ }^{1,2}$ And Hans D. Schorscher ${ }^{1}$

${ }^{1}$ Instituto de Geociências, USP, São Paulo, SP.

${ }^{2}$ BTX Serviços Geológicos, São Paulo, SP.

Presented by Antonio C. Rocha-Campos

Field work, petrographical and geochemical studies of the metavolcano-sedimentary sequence (VSS) of Piumhi-MG, a part of an Archaean or Palaeoproterozoic greenstone belt showed that current stratigraphical and petrographical classifications of this sequence require redefinition (Chiarini, 2001). Here, the VSS is formally defined as the Piumhi Supergroup, subdivided into: Lower and Upper groups (grupos Inferior and Superior) based on the Córrego Araras type-section. From base to top the Lower Group comprises: Andesitic Volcanic Unit (AVU), Magnesian Basaltic Volcanic Unit (MBVU) and Basaltic Volcanic Unit (BVU). The Upper Group, undivided here, comprises clastic and volcaniclastic metasediments with intercalated basic to acid volcanics. The Piumhi Supergroup exhibits middle greenschist facies metamorphism.

In the AVU predominate transitional tholeiitic to calc-alkaline basaltic andesites, dacites and rhyolites of fractional crystallization, altered by pre-metamorphic 
spilitization, epidotization, keratophyrization and silicification. Basaltic andesites show actinolite (substituting clinopyroxene), chlorite, albite, epidote, quartz and opaques. Porphyritic types bear relic phenocrysts of magmatic hornblende. Keratophyrized dacites and rhyolites show quartz, albite, chlorite, epidote, zircon and opaques.

Spinifex-textured MBVU-rocks have been referred to previously as komatiites or basaltic komatiites; this is not sustained mineralogically nor geochemically. These rocks present tremolite-actinolite, chlorite, albite, talc, epidote, carbonate and opaques. Pseudomorphosed acicular clinopyroxene spinifex textures predominate by far over those of bladed olivine, typical of (peridotitic) komatiites. $\mathrm{SiO}_{2}$ reaching the range of intermediate rocks, low $\mathrm{TiO}_{2}(0.25-0.40$ wt- $\%)$, and $\mathrm{Ti} / \mathrm{Zr} \sim 60$ (50-75) relegate these rocks to siliceous magnesian basalts or low-Ti tholeiites linked to boninites, rather than komatiites with $\mathrm{Ti} / \mathrm{Zr}>100$ (Coish 1989). These rocks may represent extrusive equivalents of the most primitive magmas, from which AVU-andesites differentiated in infracrustal magma chambers.

Differentiated magnesian basaltic flows show a spinifex-textured andesitic top and massive ultramafic cumulate base made up of pseudomorphosed euhedric medium-grained olivines and rare relic orthopyroxenes in a tremolite-chlorite intercumulus matrix with chromite as a constant magmatic intercumulus phase.

The BVU consists mainly of basic Fe(-Mg) tholeiitic flows. All three volcanic units contain subordinate volcaniclastic and chemical intertrap metasediments. (December 14, 2001 ).

HEAVY METAL BEHAVIOR ASSOCIATED WITH SOIL COVER USED IN THE BANDEIRANTES SANITARY LANDFILL, SÃO PAULO DISTRICT

\section{SibEle EZAKI $^{1}$ AND RAPHAEl HyPOLITO ${ }^{2}$}

${ }^{1}$ Programa de Graduação, Instituto de Geociências - USP, São Paulo, SP.

${ }^{2}$ Departamento de Geologia Sedimentar e Ambiental, Instituto de Geociências - USP, São Paulo, SP.

Presented by ANTONio C. Rocha-CAMPos

Soil used to cover compacted solid waste at sanitary landfills plays an important role in attenuating contamination by interfering in leachate composition and incorporating organic and inorganic substances. In order to investigate the behavior of metallic ions associated with the soil cover of the Bandeirantes Sanitary Landfill, Mu- nicipality of São Paulo, Brazil, we propose to assess the mobility and fixation mechanisms by simulating environmental conditions of sanitary "cells" in vitro.

The experiment will consist of glass columns, in which organic and metallic phases of an "artificial waste", will be placed upon a bed of soil and coarse sand layers, both supported on filter. Above this waste layer, a known mass of soil will be added and compacted keeping the proportions used in real sanitary landfill. Rain water or artificial rain will be allowed to percolate through the column at a rate based on known monthly precipitation. The control experiment will use soil only, taken from an intact soil profile near the landfill.

Other experiments will also reproduce the conditions equal to those in the Bandeirantes Landfill cell, but will inject rainwater and also known concentrations of heavy metals $(\mathrm{Zn}, \mathrm{Cr}, \mathrm{Pb})$. Soil chemistry will be analyzed as well as the chemical and physical-chemical properties of the leachates such as $\mathrm{pH}, \mathrm{Eh}$, temperature, humidity and DO. These parameters will be measured, as they reflect microbiological activity during aerobic and anaerobic decomposition within the landfill; the metallic ion behavior will reveal characteristics of both biochemical and physico-chemical processes. - ( December 14, 2001 ).

\section{THE OCCURRENCE OF INTERMEDIATE SCHORL- DRAVITE AND ALKALI-DEFICIENT, Cr-(V-)BEARING TOURMALINES IN THE VOLCANIC-SEDIMENTARY SEQUENCE OF THE SERRA DO ITABERABA GROUP -SP \\ Gianna M. Garda ${ }^{1}$, Paulo Beljavskis ${ }^{1}$, Caetano Juliani ${ }^{1}$ and Dailto Silva ${ }^{2}$ \\ ${ }^{1}$ Instituto de Geociências, Universidade de São Paulo, São Paulo. ${ }^{2}$ Instituto de Geociências, Universidade Estadual de Campinas, Campinas, SP.}

Presented by Antonio C. Rocha-CAmpos

In the Morro da Pedra Preta Formation, metamorphosed volcanic-sedimentary sequence of the Serra do Itaberaba Group (northeast of São Paulo City - SP), tourmalines occur in tourmalinite, metachert, iron formation, metasediments, calc-silicate and metabasic/intermediate rocks, and hosted by quartz veins. In Tapera Grande and Quartzite areas, intermediate schorl-dravite compositions predominate. Under the microscope, these tourmalines stand out for their color, zoning (alternating light and dark greenish blue tints from core to rim), and strong pleochroism (dark blue to light brown). In general, the rims are 